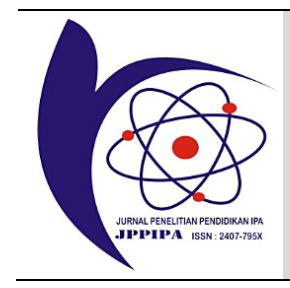

\title{
The Profile of Questioning and Reinforcement Skills of Pre-Service Teachers in Biology Learning of the Tenth Grade
}

\author{
Regiska Relanda Uthary ${ }^{1 *}$, Meilinda ${ }^{1}$, Yenny Anwar ${ }^{1}$ \\ ${ }^{1}$ Biology Education, Faculty of Teacher Training and Education, Sriwijaya University, South Sumatra, Indonesia
}

DOI: $10.29303 /$ jppipa.v8i1.899

\section{Article Info}

Received: August 18, 2021

Revised: January 15, 2022

Accepted: January 22, 2022

Published: January 31, 2022

\begin{abstract}
This study aims to find out how to apply the components of pre-service biology teachers' questioning and reinforcement skills. This study was conducted at UPT SMA Negeri 8 Ogan Ilir. The design used in this study is descriptive research. The instruments used were observation sheets and documentation in the form of video recordings. The application of basic questioning skills was seen from 7 aspects while for the application of advanced questioning skills, it is seen from 5 aspects. As for the application of reinforcement skills, it was seen from 4 aspects. The results showed that there was a difference in the number of applying questioning and reinforcement skills during the learning process. In general, pre-service teachers have implemented all components of basic and advanced questioning skills. However, the components of basic questioning skills of giving turns and distributing questions and advanced questioning skills of increasing interaction among students still rarely appear. Meanwhile, the application of the reinforcement skill components of pre-service teachers has been applied in the learning process but still tends to be monotonous.
\end{abstract}

Keywords: Pre-service teacher; Questioning skills; Reinforcement skills.

Citation: Regiska, U. R., Meilinda, M., \& Yenny, A. (2022). The Profile of Questioning and Reinforcement Skills of Pre-Service Teachers in Biology Learning of the Tenth Grade. Jurnal Penelitian Pendidikan IPA, 8(1), 316-324. https://doi.org/10.29303/jppipa.v8i1.899

\section{Introduction}

According to the Government Regulation of the Republic of Indonesia Number 57 of 2021 concerning National Education Standards, the minimum criteria for teacher competence include pedagogic, personality, social, and professional competence. A teacher must be able to manage a fun, active, and creative learning process through extensive knowledge and master skills to create a teacher that can meet the demands (Barus, et al., 2016). Teachers have a significant role in the learning process. To carry out their role properly, various basic teaching skills are needed. Through various basic teaching skills, they are expected to carry out their duties in the learning process because these skills determine the quality of the learning process (Agustina \& Saputra, 2017).

Some basic teaching skills to be mastered by teachers include questioning, reinforcement, variation, explaining, opening and closing learning, classroom management, small group discussion leadership, and small group and individual teaching skills (Shoffa, 2017). The most important thing for a teacher is how these skills are applied properly so that the learning process can run well (Sari, 2015).

Questioning skills are one of the basic teaching skills that are most often carried out during the learning process in the classroom. During the learning process, most of the interactions between teachers and preservice teachers are carried out through question-andanswer activities. In addition, the use of these questions can support other basic skills (Ermasari \& Sudria, 2014; Hussin, 2006; Ralph, 1999). Through the application of good questioning skills, the teacher can make his students actively participate in learning, direct them to understand the lesson, increase their curiosity, stimulate their imagination, motivate them, focus their attention, and keep them engaged during the learning process so 
that they play an active role in learning. Therefore, preservice teachers must understand good questioning skills (Ermasari \& Sudria, 2014)

According to the results of previous research by (Ermasari \& Sudria, 2014) on the application of teacher questioning skills in junior high school science learning in Singaraja, it was stated that teacher skills were still low. This is caused by the teacher's questioning technique that is not optimal and low-cognitive level questions. A study by Agustina \& Saputra (2017) shows that the questioning skills of pre-service teachers are not good yet. This is due to the less evenly distribution of questions that tend to be directed to certain students. Based on the study by Rasidi, et al., (2018) on questioning skills in the micro-teaching practice of elementary school teacher education students at Muhammadiyah University of Magelang, the score of teaching practice in questioning skills during microteaching was $69.41 \%$. Basic questioning skills can be classified as good enough and basic advanced questioning skills are still relatively low in the component of providing a sequence of questions. Based on the results of previous studies, the questioning skills of teachers outside Sumatra were still poor. In addition, previous studies did not include reinforcement skills because questioning skills cannot be separated from reinforcement skills.

In addition to questioning skills, the skills to provide reinforcement are also essential for teachers. Reinforcement is any form of response, both verbally and non-verbally, which is a modification of the behavior of students to provide information or feedback to students for their actions as an encouragement or correction (Usman, 2016). Reinforcement can affect the psychological behavior of students who receive it. Reinforcement is given as a positive response so that the good behavior will be repeated or improved. In the process of educative interaction, giving such a response is called reinforcement (Djamarah, 2010).

Meanwhile, research on teacher reinforcement in science learning at SMA Bukit Barisan Padang (Misra, 2012) states that the application of reinforcement still seems monotonous (not varied) and not optimal yet. This is due to the lack of skills in managing the class, causing students to be bored and not understand what the teacher is saying so that classroom learning becomes less active. The fact that only a few students are active makes unfair reinforcement so that some students feel neglected to result in a lack of enthusiasm and motivation to learn. Hisni, et al., (2017) stated that teachers faced some obstacles when giving reinforcement, namely, the lack of student response resulting in other students responding to the reinforcement with something else or joking, the teacher being confused about the suitable reinforcement for his students, and the use of monotonous reinforcement techniques causing noise during the learning process. It can be concluded from previous research that the teacher reinforcement skills are still not good yet. This can also happen in the pre-service teachers at UPT SMA Negeri 8 Ogan Ilir.

Based on the explanation above, it can be concluded that the mastery of questioning and reinforcement skills is necessary to prepare pre-service teachers. To meet the demands of the minimum criteria for teacher competence, these basic skills should be mastered by memorizing theoretically and applying them continuously. No studies explain such results. In addition, there is no data on the profile of questioning and reinforcement skills for pre-service biology teachers at Sriwijaya University implementing the teaching practice program in Ogan Ilir Regency, South Sumatra. Therefore, researchers are interested in researching the profile of questioning and reinforcement skills of senior high school pre-service teachers in biology learning to improve their skills.

The problems of this research are formulated as follows: First, how to apply the components of questioning skills proposed by pre-service biology teachers? Second, how to apply reinforcement by preservice biology teachers? Based on the formulation of the problem presented, this study aims to find out how to apply the components of questioning skills proposed by pre-service biology teachers and their skills to provide reinforcement.

\section{Method}

The design of this study is descriptive research. Descriptive research is a method that describes what is happening and a situation, condition, activities, and so on (Arikunto, 2010). Flow of the research is in the Figure 1.

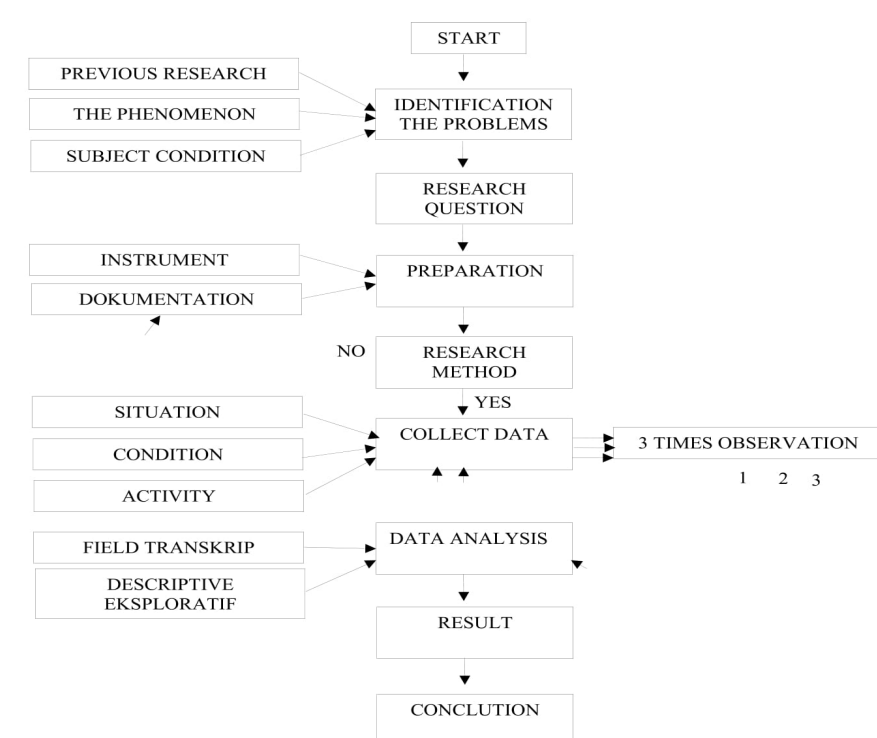

Figure 1. Flow of the research 
This study was conducted at UPT SMA Negeri 8 Ogan Ilir. This school was chosen because the researchers had teaching practice activities there and there were 6 participating pre-service teachers. This study was conducted from November 6 to 28, 2019.

The population in this study were 6 students of the Biology Education Study Program at Sriwijaya University who were carrying out teaching practice activities at UPT SMA Negeri 8 Ogan Ilir. The sample in this study was 2 pre-service teachers teaching the tenthgrade students of science.

The form of data in this study is the overall results of observations, both speech and actions, related to the skills of questioning and reinforcement for pre-service biology teachers. The data can be in the form of the number of questions asked by pre-service teachers, the number of questioning skill components that appear, the amount of reinforcement, and the type of reinforcement provided by pre-service teachers. Data collection was carried out in the field 3 times using an observation sheet that had been prepared previously.

The data were collected by using observation and documentation techniques. The observation technique was non-participatory. The researcher only acted as an observer during the learning activities. The type of observation carried out in this study was systematic observation using guidelines as an observation instrument. The documentation used in this study was in the form of photos and video recordings of teaching activities for pre-service teachers during the learning process.

The data analysis technique used was descriptive analysis which is explorative. The video recording obtained was then transcribed into a conversation. Furthermore, the transcript of the conversation was analyzed including questioning and reinforcement skills. Then, the results inputted to the observation sheet were analyzed to find out whether each component had been applied to each skill. The questions were identified based on the use of $5 \mathrm{~W}+1 \mathrm{H}$ and voice intonation when the teacher asked questions and showed gestures to stimulate their students to answer.

Table 1. Criteria of Basic Teaching Skill (Hakim, et al., 2020)

\begin{tabular}{ll}
\hline Average $(\%)$ & Criteria \\
\hline $85-100$ & Very Skilled \\
$70-84$ & Skilled \\
$55-69$ & Enough Skilled \\
$40-54$ & Less Skilled \\
$0-39$ & Least Skilled \\
\hline
\end{tabular}

\section{Result and Discussion}

In this section, the results are divided into 2 about the basic skills of questioning and reinforcement carried out by pre-service teachers. This study was conducted from November 6 to 28, 2019 at UPT SMA Negeri 8 Ogan Ilir. The study was carried out three times for each preservice teacher in the two learning hours.

\section{Questioning Skills during Learning Activities}

Good questions were noted during the opening, core, and closing activities. The questions were identified based on the use of $5 \mathrm{~W}+1 \mathrm{H}$ and voice intonation when the teacher asked questions or showed gestures by raising his hand to stimulate the students to answer. The number of pre-service teacher questions obtained is shown in Table 2.

Table 2. Frequency of Questioning Skills

\begin{tabular}{|c|c|c|c|c|c|}
\hline \multirow{2}{*}{ Teacher } & \multirow{2}{*}{ Meeting } & \multicolumn{3}{|l|}{ Activities } & \multirow{2}{*}{ Total } \\
\hline & & Opening & Core & Closing & \\
\hline \multirow{3}{*}{ A } & 1 & 5 & 25 & 4 & 34 \\
\hline & 2 & 7 & 28 & - & 35 \\
\hline & 3 & 8 & 17 & - & 25 \\
\hline Mean & & 6.67 & 23.33 & 1.33 & 31.33 \\
\hline \multirow{3}{*}{ C } & 1 & 10 & 29 & - & 39 \\
\hline & 2 & 8 & 11 & - & 19 \\
\hline & 3 & 8 & 16 & 2 & 26 \\
\hline Mean & & 8.67 & 18.67 & 0.67 & 28 \\
\hline
\end{tabular}

Table 2. shows that there are differences in the number of questions in each activity in each lesson. In the opening and core activities, both teachers asked varying numbers of questions. However, in the closing activity, they seemed very lacking in asking questions. In several meetings, they seldom asked questions in the closing activities.

Based on the results of observations on the two preservice teachers, there were differences in the number of questions asked during the learning process. The difference in the number of questions asked can be caused by several factors. Factors that influence include differences in the level of mastery of learning materials, characteristics of students, and time constraints (Martino \& Maher, 1994). A low level of mastery of the material can result in differences in the number of questions asked. The lack of mastery of the material is indicated by the lack of preparation of teaching materials so that preservice teachers cannot prepare the questions well to be asked during learning (Nurlaili, 2018). This is supported by the interviews with the pre-service teachers who said that the source of the teaching materials used still depended on the student textbooks.

Based on the observations during learning, the differences in the characteristics of students also resulted in a different number of questions. For example, when the teacher asked a question, some students immediately sought the answers independently and some were even busy with themselves so that the questions given could not be developed. This made pre-service teachers spend a lot of time telling or guiding the students to focus on ongoing learning. In addition, time constraints resulted 
in teachers being unable to ask questions in the closing activity in some meetings.

The pre-service teachers also often asked questions by completing sentences. They gave complementary questions during the observation. Meanwhile, teacher B gave 20 incomplete sentences. This was done because such questions were considered to guide the students and provoke them to answer more easily.
The Application of Basic Questioning Skill Components

The results of the analysis of the application of the basic questioning components were then converted into percentages so that the following results were obtained (Table 3).

Table 3. The Application of Basic Questioning Skill Components of Teacher A

\begin{tabular}{|c|c|c|c|c|c|}
\hline \multirow{2}{*}{ Basic Questioning Components } & \multicolumn{3}{|c|}{ Meeting (\%) } & \multirow[t]{2}{*}{ Mean (\%) } & \multirow[t]{2}{*}{ Criteria } \\
\hline & 1 & 2 & 3 & & \\
\hline Clear and Concise & 100 & 100 & 96 & 98.67 & Very Skilled \\
\hline Providing reference & 50 & 51.43 & 64 & 55.14 & Skilled Enough \\
\hline Focusing & 79.41 & 62.86 & 52 & 64.76 & Skilled Enough \\
\hline Giving turns and distribution & 1.65 & 17.14 & 20 & 18.26 & Least Skilled \\
\hline Providing time to think & 100 & 20 & 68 & 89.33 & Very Skilled \\
\hline Guiding & 17.65 & 18.26 & 20 & 17.31 & Least Skilled \\
\hline Avoiding bad habit & 44.12 & 34.29 & 24 & 34.13 & Least Skilled \\
\hline Total Mean & & & & 53.94 & Less Skilled \\
\hline
\end{tabular}

Table 3 shows that overall, the basic skill components have been applied by teacher $\mathrm{A}$. The results of the application of basic questioning skills of teacher A are categorized as less skilled. Meanwhile, the application of teacher B's basic questioning skills is shown in Table 4.

Table 4. The Application of Basic Questioning Skill Components of Teacher B

\begin{tabular}{llllll}
\hline \multirow{2}{*}{ Basic Questioning Components } & \multicolumn{2}{l}{ Meeting (\%) } & \multicolumn{2}{c}{ Mean (\%) } & Criteria \\
\cline { 2 - 5 } & 1 & 2 & 3 & 98.72 & Very Skilled \\
\hline Clear and Concise & 100 & 100 & 96.15 & 73.41 & Skilled \\
Providing reference & 76.92 & 98.47 & 53.85 & 78.79 & Skilled \\
Focusing & 79.49 & 68.45 & 88.46 & 20.18 & Least Skilled \\
Giving turns and distribution & 15.38 & 10.53 & 34.62 & 95.25 & Very Skilled \\
Providing time to think & 94.87 & 94.74 & 96.15 & 30.57 & Least Skilled \\
Guiding & 38.46 & 26.32 & 26.92 & 26.72 & Least Skilled \\
Avoiding bad habit & 23.08 & 26.32 & 30.77 & 60.25 & Skilled Enough \\
Total Mean & & & & & \\
\hline
\end{tabular}

Based on Table 4, overall, the basic questioning skill components have been implemented by teacher $\mathrm{B}$. Both teachers have implemented the components of expressing questions clearly and briefly. Based on the observation made, the questions posed can be directly answered by the students. This shows that the questions of the teacher can be understood by students. This is in line with Nurlaili (2018) stating that the questions posed by pre-service teachers are simple and understandable for students so that they are stimulated to think.

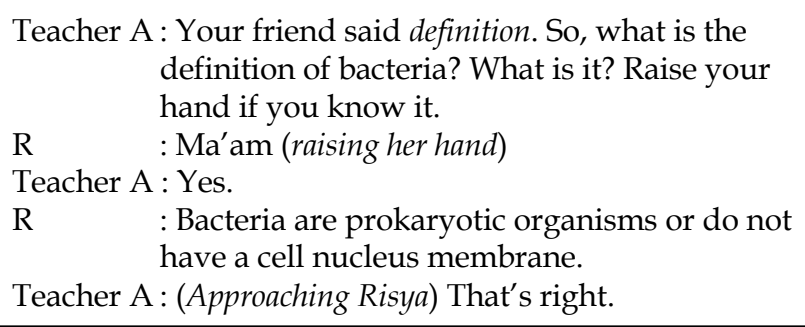
definition of bacteria? What is it? Raise your hand if you know it.

$\mathrm{R} \quad$ : Ma'am (raising her hand)

Teacher A : Yes.

$\mathrm{R} \quad$ : Bacteria are prokaryotic organisms or do not have a cell nucleus membrane.

Teacher A : (Approaching Risya) That's right.

Figure 2. The Example of Application of Clear and Concise Question Components for Pre-Service Teacher A
The application of providing reference by teacher A is categorized as skilled enough with a percentage of $55.14 \%$. Based on the observation, this was caused by teacher A's lack of mastering the material taught. Teacher A only used the teaching materials. Teacher A tends to ask questions directly without conveying information first. Meanwhile, teacher B was categorized as skilled with a percentage of $73.71 \%$.

The third component is focusing. Focusing questions is categorized as skilled enough with a percentage of $64.76 \%$. Meanwhile, teacher B applied this component skillfully with a percentage of $78.79 \%$. This can be seen when the two teachers asked questions that lead to certain answers. This is as stated by Nurlaili (2018) that pre-service teachers also focus questions on one answer. The questions asked by the teacher have a narrow scope so that they require students to pay more attention to specific things.

The application of the fourth basic questioning component is giving turns and distributing questions. In the application of this component, the two teachers were 
the least skilled. During class observations, when asking the students, the teachers only asked one student. If the student's answer is inaccurate, they add and complete the answer instead of asking other students to respond to the first student's answer. This finding is in line with that stated by Luzyawati, (2015) that the questions asked by pre-service teachers are not evenly distributed. They tend to ask another student who is considered able to answer because, through his answer, the other students will listen to the answer that is easier to understand.

\section{Teacher B : These are gram positive and gram-negative bacteria. What is gram positive bacteria? \\ Haiqal : The cell wall is simpler. It contains a lot of peptidoglycans. \\ Teacher B : What is peptidoglycan? \\ Haiqal : That's virus. Isn't it virus? Like Micrococcus. \\ Teacher B : No. Peptidoglycan is a rigid cell wall.}

Figure 1. The Example of Application of Giving Turns and Distributing Questions for Pre-Service Teacher B

The fifth component is giving time to think (wait time). It was done very well by the two pre-service teachers. They waited for about 5 seconds or until the students raised their hands first before asking one of them to answer. The next component is guiding. Both teachers applied it very poorly. If the students find it difficult to answer questions, both teachers often ask the same question and do not explain the material related to the question. It is not uncommon for the teachers to directly answer the questions asked. This is in line with the finding of Agustina \& Saputra, (2017) showing that when students tend to be silent when asked a question, the teacher immediately answers it. They should be able to encourage the students to be more active, creative, and think independently to find the answer. Meanwhile there will be positive effects when the wait time after teacher questions (and student responses) is extended (Heinze \& Erhard, 2006)

For the implementation of avoiding bad habits, both teachers are still very lacking. They often repeat the answers given by the students. Many questions they asked triggered the students to answer together. In addition, on several occasions, pre-service teachers appointed certain students to answer new questions.

\section{The Application of Advanced Questioning Skill Components}

Basic questioning skills are followed by advanced questioning skills. The application of advanced questioning skill components by teacher A can be seen in Table 5.

Table 5. The Application of Advanced Questioning Skill Components of Teacher A

\begin{tabular}{llllll}
\hline \multirow{2}{*}{ Advanced Questioning Skills } & \multicolumn{2}{c}{ Meeting (\%) } & \multirow{2}{*}{ Mean (\%) } & Criteria \\
\cline { 2 - 5 } & 1 & 100 & 60 & 64.44 & Skilled Enough \\
\hline Changes in cognitive guidance & 33.33 & 100 & 60 & 64.44 & Skilled Enough \\
Cognitive sequencing & 33.33 & 100 & 60 & 64.44 & Skilled Enough \\
Tracking question & 33.33 & 0 & 80 & 37.78 & Least Skilled \\
Increasing interaction & 33.33 & & 57.78 & Skilled Enough \\
Total Mean & & & & & \\
\hline
\end{tabular}

Based on the data from Table 5, teacher A has implemented all components of advanced questioning skills. Overall, teacher $\mathrm{A}$ is skilled enough. For the application of teacher B, it is shown in Table 6 .

Table 6. The Application of Advanced Questioning Skill Components of Teacher B

\begin{tabular}{|c|c|c|c|c|c|}
\hline \multirow{2}{*}{ Advanced Questioning Skills } & \multicolumn{3}{|c|}{ Meeting (\%) } & \multirow[b]{2}{*}{ Mean (\%) } & \multirow{2}{*}{ Criteria } \\
\hline & 1 & 2 & 3 & & \\
\hline Changes in cognitive guidance & 84.62 & 83.33 & 37.5 & 68.48 & Skilled Enough \\
\hline Cognitive sequencing & 84.62 & 83.33 & 37.5 & 68.48 & Skilled Enough \\
\hline Tracking question & 53.85 & 16.67 & 37.5 & 36 & Least Skilled \\
\hline Increasing interaction & 23.08 & 50 & 87.5 & 53.53 & Less Skilled \\
\hline Total Mean & & & & 56.62 & Skilled Enough \\
\hline
\end{tabular}

Based on the data from Table 5, teacher B has implemented all components of advanced questioning skills. Like teacher A, teacher B is also quite skilled. The components of changing cognitive guidance and cognitive sequencing of the two teachers have been applied quite skillfully. Based on the observations, they asked more difficult questions. However, the level of questions asked is only at the level of applying. This finding is in line with Luzyawati, (2015) stating that the questions asked by pre-service teachers have a low level of difficulty. Fewer higher-order cognitive questions were asked because the teacher did not plan it. Even novice teacher have good questioning skill, but advanced questioning skills need to be improved due to requires an in-depth knowledge (Martino \& Maher, 1994; Sari \& Hasibuan (2019). Darmadi, et al., (2020) stated that pre-service teacher tent to ask low-level 
questions. They were not accustomed to asking questions with the evaluating and creating level.

The application of the tracking question component of teacher A can be categorized as skilled enough while that of teacher $B$ is the least skilled. During the observation, the questions given led to a single correct answer. When a student's answer was inaccurate or they had difficulty answering, the pre-service teacher did not direct him to find the right answer but will immediately correct it.

\begin{tabular}{|ll|}
\hline Teacher B & $\begin{array}{l}\text { : OK. Back to the laptop. Today, we will } \\
\text { learn about bacteria. What kingdom } \\
\text { does bacteria belong to? In which } \\
\text { kingdom is it? Prokary? }\end{array}$ \\
A & $\begin{array}{l}\text { : Prokaryote. } \\
\text { : Does your book explain what is meant } \\
\text { by prokaryote? }\end{array}$ \\
Peacher B & $\begin{array}{l}\text { : It does not have a cell nucleus } \\
\text { membrane. }\end{array}$ \\
Teacher B & : It does not have a membrane.
\end{tabular}

Figure 2. The Example of Application of Tracking Question Component of Teacher $\mathrm{B}$

For the component of increasing interaction among students, the two teachers were less skilled. When the students asked questions, the teachers immediately answered; they did not ask other students. In addition, the students tend to be passive in asking questions during the learning process. This is in line with Asmira, et al., (2014) stating that the increase in interaction is not optimal because, during learning, students are still less active in asking questions and tend to be silent and do not participate when asked questions.

\begin{tabular}{|ll|}
\hline Teacher A & : Yes (nodding), E. Coli. There's a tube \\
& prepared for this bacterium. In this \\
small tube, it is inserted to the very & bottom. If the tube is lifted, it means \\
& that it contains gases. What does it \\
& mean? \\
& : Good bacteria. \\
One student & : No. Bad bacteria too. It is Salmonella. \\
Teacher A & : Salmonella. \\
All students &
\end{tabular}

Figure 3. The Example of Application of Increasing Interaction Component among Students of Pre-Service Teacher A

\section{Reinforcement Skills during Learning Activities}

The reinforcement given during the learning process was observed from the video. The reinforcement given tends to be varied during the opening, core, and closing activities (Table 7).
Table 7. Frequency of Reinforcement Skills

\begin{tabular}{|c|c|c|c|c|c|}
\hline \multirow{2}{*}{ Teacher } & \multirow{2}{*}{ Meeting } & \multicolumn{3}{|l|}{ Activities } & \multirow{2}{*}{ Total } \\
\hline & & Opening & Core & Closing & \\
\hline \multirow{3}{*}{ A } & 1 & 7 & 25 & 2 & 34 \\
\hline & 2 & 9 & 24 & - & 33 \\
\hline & 3 & 19 & 17 & - & 36 \\
\hline Mean & & 11.67 & 22 & 0.67 & 34.33 \\
\hline \multirow{3}{*}{ C } & 1 & 6 & 18 & - & 24 \\
\hline & 2 & 6 & 5 & 3 & 14 \\
\hline & 3 & 7 & 26 & 1 & 34 \\
\hline Mean & & 6.3 & 16.33 & 1.33 & 24 \\
\hline
\end{tabular}

Based on Table 7, there are differences in giving reinforcement in each learning activity. In the opening and core activities, both teacher $\mathrm{A}$ and teacher $\mathrm{B}$ provided reinforcement in varying amounts during learning. However, in the closing activity, teacher A rarely gave reinforcement while teacher $\mathrm{B}$ gave some. These differences occur due to differences in the characteristics of students in responding to something.

\section{The Application of Reinforcement Skill Components}

Reinforcement is giving a positive response in learning to the positive behavior of students. The analysis of the application of the reinforcement component was then formulated in the form of a percentage so that the following results were obtained (Table 8).

Table 8. The Application of Reinforcement Skill Components of Teacher A

\begin{tabular}{lllll}
\hline \multirow{2}{*}{ Reinforcement Indicator } & \multicolumn{3}{l}{ Meeting (\%) } & Mean \\
\cline { 2 - 4 } & 1 & 2 & 3 & $(\%)$ \\
\hline Verbal & 73.53 & 84.85 & 69.44 & 75.94 \\
Expression & 5.88 & 0 & - & 1.96 \\
Body movement & 26.47 & 15.15 & 16.67 & 19.43 \\
Approaching & 29.41 & 27.27 & 33.33 & 30.00 \\
Touching & - & 3.03 & - & 1.01 \\
Symbol/thing & - & - & - & - \\
Fun activities & - & - & - & - \\
Not full & 2.94 & 0 & 11.11 & 4.68 \\
Individual & 97.06 & 93.94 & 91.67 & 94.22 \\
Group & 2.94 & 6.06 & 8.33 & 5.78 \\
Done immediately & 94.12 & 84.85 & 77.78 & 85.58 \\
Warm and enthusiastic & 79.41 & 72.73 & 63.89 & 72.01 \\
Meaningful & 76.47 & 57.58 & 66.67 & 66.91 \\
\hline
\end{tabular}

Table 8 . shows that the reinforcement given by teacher A is mostly done verbally $(75.11 \%)$. Non-verbal reinforcement is mostly done by approaching students and occasionally body movements. 
Teacher A : Now I want to ask. What can you conclude from the video? Please raise your hand.

$\mathrm{V} \quad$ : The bad virus can be eradicated with the good one contained in Dancow's milk.

Teacher A : That's right. Any other? Who wants to answer again?

$\mathrm{R} \quad$ : Ma'am (raising her hand). Diarrhea is caused by bad bacteria.

Teacher A : (Approaching Restya). Yes (nodding).

$\mathrm{R} \quad$ : And the good bacteria are outnumbered by the bad bacteria.

Teacher A : Correct (giving a thumb up).

Figure 4. The Example of Application of Reinforcement of Pre-Service Teacher A

Slightly different from teacher A, teacher B performed verbal and non-verbal reinforcement in a balanced way. The application of reinforcement by teacher B can be seen in Table 8 .

Table 9. The Application of Reinforcement Skill Components of Teacher B

\begin{tabular}{lllll}
\cline { 1 - 4 } Reinforcement & \multicolumn{3}{l}{ Meeting (\%) } & \multirow{2}{*}{ Mean \%) } \\
\cline { 2 - 4 } Indicator & 1 & 2 & 3 & \\
\hline Verbal & 70.83 & 57.14 & 55.88 & 61.29 \\
Expression & - & - & - & - \\
Body movement & 41.67 & 42.86 & 29.41 & 37.98 \\
Approaching & 25 & 35.71 & 41.18 & 33.96 \\
Touching & - & - & - & - \\
Symbol/thing & - & - & - & - \\
Fun activities & - & 7.14 & - & 2.38 \\
Not full & 8.33 & 28.57 & 2.94 & 13.28 \\
Individual & 91.67 & 85.71 & 67.65 & 81.68 \\
Group & 8.33 & 14.29 & 32.35 & 18.32 \\
Done immediately & 91.67 & 64.29 & 100 & 85.32 \\
Warm and & 75 & 71.43 & 64.71 & 70.38 \\
enthusiastic & 79.17 & 71.43 & 52.94 & 67.85 \\
Meaningful & & & & \\
\hline
\end{tabular}

Table 9 shows that the application of reinforcement by teacher $B$ is in the form of not only verbal but also non-verbal reinforcement. Non-verbal reinforcement is mostly done by body movements in the form of nodding and clapping.

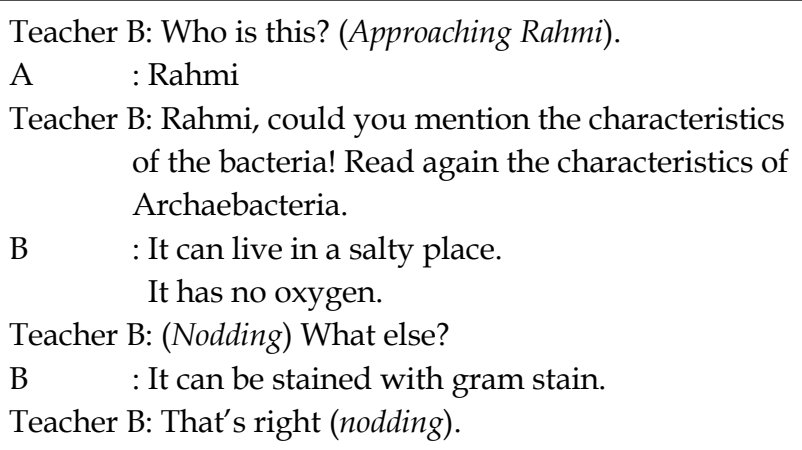

Figure 5. The Example of Application of Reinforcement of Pre-Service Teacher B
Overall, the skills to provide reinforcement have been carried out skillfully. Both pre-service teachers have implemented verbal reinforcement. However, the use of verbal reinforcement tends to be monotonous. The words used are correct, right, yes. This is in line with the finding of Hisni, et al., (2017) stating that the diction used by the teacher in verbal reinforcement is limited. No other verbal reinforcement diction was found other than the good, correct, right, and pretty good. Monotonous diction tends to be used because it is easy and very common. In addition, the use of diction alone can make students feel happy.

The application of verbal reinforcement is often followed by non-verbal reinforcement as shown in Figures 5 and 6 . The most frequently applied non-verbal reinforcements are body movement and approaching students. However, there are slight differences for each pre-service teacher. Teacher A often applies body movement reinforcement in the form of thumbs up to students while teacher B applies body movements in the form of clapping to appreciate students. The application of reinforcement by approaching is often done by both teachers when students answer questions and have discussions or difficulties when answering questions. This is in line with Hisni, et al., (2017) stating that teachers do non-verbal reinforcement in the form of approaching when appointing students to answer the questions asked. The use of approaching reinforcement is to motivate the students to think about finding answers and be active in learning. The finding of Aida \& Antoni (2017) showing that pre-service teachers used of praise word and statement in the class. Fitrianti et al. (2020) state that teachers in the present study employ three type of reinforcement. The reinforcement are verbal reinforcement, token reward, and tangible reward. Symbolic reward and activity reward did not use in their teaching and learning process. These strategies are not used as they appear to spend much money and take time.

\section{Conclusion}

Based on the finding, it can be concluded that there are differences in the number of skills in the application of questioning and reinforcement during learning. In general, the two pre-service teachers have applied the questioning components quite skillfully. In the application of basic questioning skills, pre-service teacher A obtained a percentage of 53.94\% (less skilled) and pre-service teacher B obtained 60.25\% (skilled enough). In advanced questioning skills, pre-service teacher A obtained $57.78 \%$ (skilled enough) and preservice teacher B obtained 56.62\% (skilled enough). Both teachers have applied the reinforcement skill components in the learning process, but they are not skilled yet. Pre-service teachers apply more verbal 
reinforcement than non-verbal. The reinforcement has fulfilled the principles of warmth, enthusiasm, and meaning.It is recommended that pre-service biology teachers improve their experience in applying questioning and reinforcement skills, avoiding bad habits during questioning, as well as preparing for better learning, and increasing the application of non-verbal reinforcement.

\section{References}

Agustina, P., \& Saputra, A. (2017). Profil keterampilan dasar mengajar mahasiswa calon guru biologi pada matakuliah microteaching. Jurnal Bioedukatika, 5(1), 18. https://doi.org/10.26555/bioedukatika.v5i1.5670

Aida, W. \& Antoni, R. (2017). Basic Components of Micro Teaching Skill at Third Year Students FKIP Universitas Pasir Pengaraian. Journal of English Education, 3(2), 100-112. https://journal.upp.ac.id/index.php/JEE/article $\angle$ view $/ 512$

Arikunto, S. (2010). Prosedur Penelitian: Suatu Pendekatan Praktik. Rineka Cipta.

Asmira, A., Rivaie, T., \& Salim, I. (2014). Analisis keterampilan bertanya oleh guuru mata pelajaran sosiologi pada kelas $\mathrm{x}$ mas khulafaur rasyidin. Jurnal Pendidikan Dan Pembelajaran Khatulistiwa, 3(10), 1-10. Retrieved from https://jurnal.untan.ac.id/index.php/jpdpb/arti cle/view/7686

Barus, Z., Siagian, S., \& Purba, S. (2016). Upaya Peningkatan Keterampilan Dasar Mengajar Guru Melalui Supervisi Klinis Dengan Pendekatan Kolaboratif Di SMK Negeri 1 Berastagi Kabupaten Karo. Jurnal Pendidikan Dan Kepengawasan, 3(2), 1632.

https://jurnal.unimed.ac.id/2012/index.php/jpd $\mathrm{k} /$ article/view/7882

Darmadi, D., \& Putra, R, A. (2020). The Low Level of Biology Teacher Candidate Questioning. Jurnal Pendidikan Biologi Indonesia, 6(1), 47-54. Retrieved from

https://ejournal.umm.ac.id/index.php/jpbi/artic le/view/10503

Djamarah, S. B. (2010). Guru dan Anak Didik dalam Interaksi Edukatif, Suatu Pendekatan Teoritis Psikologis. Jakarta: Rineka Cipta.

Ermasari, G., \& Sudria, M. (2014). Kemampuan Bertanya Guru IPA Dalam Pengelolaan Pembelajaran. Jurnal Pendidikan Dan Pembelajaran IPA Indonesia, 4(1). Retrieved from https://ejournalpasca.undiksha.ac.id/index.php/jurnal_ipa/articl e/view/1111

Fitrianti, S.W., Fatmala, D., \& Anjaniputra, A.G. (2020). Teachers' Classroom Instruction Reinforcement
Strategies in English Language Class. Journal of Education and Learning, 14(4), 599-608. Retrieved from https://eric.ed.gov/?id=EJ1276485

Hakim , N., Yudiyanto, Hakiki, P.R.L., \& Soleha, S. (2020). Analisis Keterampilan Dasar Mengajar Mahasiswa Tadris Biologi. Jurnal Pendidikan Biologi, 5(1), 56-63. http://dx.doi.org/10.31932/jpbio.v5i1.576

Heinze, A \& Erhard, M. (2006). How much time do students have to think about teacher questions? An investigation of the quick succession of teacher questions and student responses in the German mathematics classroom. ZDM Mathematics Education, 38(5), 388-398. http://dx.doi.org/10.1007/BF02652800

Hisni, M., Sutresna, I., \& Si, M. (2017). Teknik Penguatan dalam Pembelajaran Menulis di Kelas X IPB MAN Patas Kecamatan Grokgak. E-Journal Universitas Pendidikan Ganesha, 6(1), 1-12. Retrieved from http://ejournal.undiksha.ac.id/index.php/JJPBS Larticle/view/9684

Hussin, H. (2006). Dimensions of Questioning: A Qualitative Study of Current Classroom Practice in Malaysia. Tesl-Ej, 10(2), 1-18. https://ethos.bl.uk/OrderDetails.do?uin=uk.bl.et $\underline{\text { hos.524286 }}$

Luzyawati, L. (2015). Profil Tingkat Penguasaan Keterampilan Dasar Mengajar Mahasiswa Calon Guru Biologi. Jurnal Pengajaran Matematika Dan Ilmu Pengetahuan Alam, 20(1), 88. https://doi.org/10.18269/jpmipa.v20i1.568

Martino, A.M., \& Maher, C.A. (1994). Teacher questioning to stimulate justification and generalization in mathematics. New Orleans, LA: Paper presented at the Annual Meeting of the American Educational Research Association

Misra, M. (2012). Reinforcement Skill dalam Pembelajaran PAI (Studi Kasus di SMA Bukit Barisan Padang). Al-Ta Lim Journal, 19(1), 38-45. https://doi.org/10.15548/it.v19i1.7

Nurlaili, N. (2018). Analisis Keterampilan Dasar Mengajar Guru Dalam Perspektif Guru Pamong Pada Mahasiswa Prodi PGMI Fakultas Ilmu Tarbiyah dan Keguruan UIN Raden Fatah Palembang. JIP: Jurnal Ilmiah PGMI, 4(1), 28-40. https://doi.org/10.19109/jip.v4i1.2270

Ralph, E. G. (1999). Developing novice teachers' oralquestioning skills. Mcgill Journal of Education, 34(1), 29-47. Retrieved from https://go.gale.com/ps/i.do?id=...7Eb85b79c8

Rasidi, Mayawati, A. I., \& Sari, S. W. (2018). Studi Keterampilan Bertanya Dalam Praktek Micro Teaching Mahasiswa PGSD. The 7th University Research Colloqium, 283-290. Retrieved from http://repository.urecol.org/index.php/proceedi ng/article/view/132/129 
Sari, F.M. (2015). Kemampuan Guru Memberi Penguatan

Semarang [Universitas Negeri Semarang]. http://lib.unnes.ac.id/21544/1/1401411199-s.pdf

Sari, N.P., \& Hasibuan, W.F. (2019). Teacher's Questioning Skills and Students' Responses in Science Subject Based on Parenting Style Perspectives. Jurnal Pendidikan Bilogi Indonesia, 5(1), 85-92. Retrieved from https://ejournal.umm.ac.id/index.php/jpbi/artic le/download/7023/6534

Shoffa, S. (2017). Keterampilan Dasar Mengajar Microteaching. In Penerbit mavendra Pers (Issue 9). Mavendra Pers.

Usman., M. U. (2016). Menjadi Guru Profesional. PT Remaja Rosdakarya 